\title{
REVOLUÇÃO DE 1930
}

\author{
1930 Revolution
}

Revolución de 1930

MARCO AURÉlIO VANNUCCHI ${ }^{{ }^{*}}$

DOI: http://dx.doi.org/10.1590/S2178-14942020000300001

'Escola de Ciências Sociais, Fundação Getulio Vargas - Rio de Janeiro (RJ), Brasil.

*Editor convidado. Professor da Escola de Ciências Sociais, Fundação Getulio Vargas (marco.vannucchi@fgv.br).

(D) https://orcid.org/0000-0002-6481-8720 


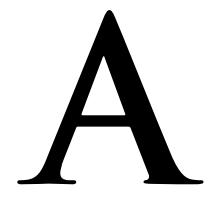

Revolução de 1930 e o regime instalado a partir de então foram examinados nas décadas de 1960 e 1970 por um conjunto de autores que nos legaram uma valiosa visão abrangente. Pertencentes às primeiras gerações de cientistas sociais profissionalizados no Brasil, esses autores realizaram trabalhos de grande fôlego empírico e densidade teórica. Uma parte significativa dessa produção derivou de doutorados cursados nos pioneiros programas de pós-graduação em Ciências Sociais do país ou em prestigiadas universidades estadunidenses e europeias. Os historiadores chegaram mais tarde a esse campo de estudos, e apenas na passagem para a década de 1980 sua produção tomou volume. Constituída por trabalhos de alto nível acadêmico, a historiografia acerca da Era Vargas empenhou-se pouco em oferecer análises generalizantes. Ainda assim, contribuiu para o conhecimento mais aprofundado de determinados aspectos do período, destacadamente as condições de vida, a organização política e o relacionamento com o Estado dos grupos subalternos urbanos. Não tendo sido capaz de oferecer uma interpretação de conjunto alternativa à literatura proveniente das Ciências Sociais, a historiografia fez alguns reparos pertinentes e matizou determinadas análises. 0 artigo de Elizabeth Cancelli, publicado nesta edição de Estudos Históricos, faz um inventário dessa produção.

A grade de leitura que recorre ao livro de Barrington Moore (1967) para compreender o significado histórico da Revolução de 1930 e a natureza do regime varguista continua a provar sua grande capacidade heurística. Assim, 1930 constitui um marco decisivo na passagem da sociedade tradicional (agrário-rural) para a sociedade moderna (urbano-industrial). Tratou-se de incentivar o desenvolvimento do capitalismo brasileiro cuidando para que a ordem social fosse mantida a mais preservada possível. 0 Estado, que já atuava na Primeira República como agente de amparo à cafeicultura, alçou o seu intervencionismo na economia a outro patamar e passou a dar guarida a um leque mais amplo de interesses. A política econômica de Vargas é estudada no artigo de Antonio Lassance.

Há um bloco de artigos que exploram tensões, impasses e soluções criadas no âmbito da modernização conservadora, premida entre a necessidade de, por um lado, atrair e, por outro, de controlar os trabalhadores das cidades. A postura ambivalente do Estado pós-1930 perante a questão social é explorada tanto no artigo de Marly Vianna quanto no de Marcelo Sevaybricker Moreira e Ronaldo Teodoro dos Santos. Já o artigo de Andrei Koerner e o de Douglas Souza Angeli analisam as elaborações ideológicas que enfrentaram a questão da extensão de direitos aos pobres. Antonio Luigi Negro e Jonas Brito demonstram a capacidade de ação política dos de baixo, que colocava em risco a revolução pelo alto no Brasil. Pros- 
seguindo a apresentação deste número da revista, há um trio de artigos que oferecem uma contribuição importante para a compreensão da reestruturação do poder político a partir de 1930. Jaqueline Porto Zulini e Paolo Ricci vislumbram o Código Eleitoral de 1932 como um recurso de poder a serviço do novo regime, enquanto Eliana Evangelista Batista investiga a incorporação de chefes locais baianos ao compromisso que se formou em torno de Vargas. Finalmente, Carolina Soares Sousa, ao centrar-se na figura de Paulo Duarte, ilumina o movimento de aproximações e distanciamentos de parte da oligarquia paulista em relação ao governo central.

\section{REFERÊNCIAS BIBLIOGRÁFICAS}

MOORE, B. Social origins of dictatorship and democracy. Beacon Press: Boston, 1967. 